\title{
ESTIMASI MODEL DINAMIS NUTRISI YANG TIDAK BAIK DAN MALNUTRISI DI PROVINSI SULAWESI SELATAN
}

\section{ESTIMATION DYNAMICAL MODEL OF INSUFFICIENT NUTRITION AND MALNUTRITION IN SOUTH SULAWESI PROVINCE}

\author{
Andi Nur Utami ${ }^{1}$, Ridwan Amiruddin ${ }^{2}$, Andi Hardianti, Tahir Abdullah ${ }^{3}$ \\ 1Program Magister Epidemiologi Unhas Makassar, andi.nur.utami@gmail.com \\ ${ }^{2}$ Staf Pengajar Epidemiologi FKM Unhas, ridwan.amiruddin@gmail.com \\ ${ }^{3}$ Staf Pengajar Biostatistik/KKB FKM Unhas, mtahirabd@gmail.com
}

Alamat Koresponden: Dinas Pendidikan Kabupaten Maros, Email: andi.nur.utami@gmail.com

\begin{abstract}
ABSTRAK
Hampir setengah dari kematian balita di dunia berkaitan dengan masalah gizi kurang dan gizi buruk. Tujuan penelitian ini adalah untuk mengestimasi prevalensi gizi kurang dan gizi buruk selama 18 tahun (2007 - 2025) dan strategi penanggulangan yang paling sesuai dalam menurunkan prevalensi gizi kurang dan gizi buruk dengan pendekatan model dinamik di Sulawesi Selatan. Penelitian ini adalah deskriptif dengan menggunakan data sekunder yang berasal dari data Riskesdas dan Profil Kesehatan Provinsi Sulawesi Selatan. Sampel penelitian berupa data gizi kurang, gizi buruk, pemberian ASI eksklusif, pemberian kapsul vitamin A dan imunisasi dasar lengkap. Data dianalisis melalui sistem dinamis dengan menggunakan program powersim. Validasi model menggunakan uji t 2 sampel independen. Hasil penelitian menunjukkan bahwa prevalensi gizi kurang dan gizi buruk pada tahun 2025 menurun menjadi 18.06\% dengan laju penurunan rata-rata sebesar $0.014 \%$ per tahun. Berbagai program penanggulangan gizi kurang dan gizi buruk dapat menurunkan prevalensi gizi kurang dan gizi buruk, penimbangan balita di posyandu $0.073 \%$ per tahun, pemberian ASI eksklusif $0.037 \%$ per tahun, dan imunisasi dasar lengkap $0.122 \%$ per tahun. Penelitian menyimpulkan bahwa jika cakupan penimbangan balita di posyandu, pemberian ASI eksklusif dan imunisasi dasar lengkap dapat ditingkatkan maka dapat membantu percepatan penurunan prevalensi gizi kurang dan gizi buruk.
\end{abstract}

Kata kunci: Estimasi, model dinamis, gizi kurang, gizi buruk

\begin{abstract}
Almost half of under-five deaths in the world related to the problem of insufficient nutrition and mal nutrition. The purpose of this study was to estimate the prevalence of insufficient nutrition and mal nutrition for 18 years (20072025) and the handling strategy of the most appropriate way to lower the prevalence of insufficient nutrition and mal nutrition with dynamic models in South Sulawesi Province. This is a descriptive study using secondary data derived from the data Riskesdas and Health Profile of South Sulawesi province. The research sample of data in the form of insufficient nutrition, mal nutrition, exclusive breast milk giving, vitamin A capsule administration and complete basic immunization. Data were analyzed through dynamic systems using powersim program. Validation of the model using two independent samples $t$ test. The results showed that the prevalence of insufficient nutrition and mal nutrition in 2025 decreased to $18.06 \%$ by an average rate of increase of $0.014 \%$ per year. Various control programs of insufficient nutrition and mal nutrition can reduce the prevalence of insufficient nutrition and mal nutrition, weighing under five children at posyandu $0.073 \%$ per year, exclusive breast milk giving $0.037 \%$ per year and complete basic immunization $0.122 \%$ per year. This research concludes that if the coverage of weighing under five children at posyandu, exclusive breast milk giving and complete basic immunization can be improved, it can help accelerate a decrease in the prevalence of insufficient nutrition and mal nutrition.
\end{abstract}

Keywords: Estimation, dynamic model, insufficient nutrition, mal nutrition 
PENDAHULUAN

Hampir setengah dari kematian balita di dunia berkaitan dengan masalah gizi kurang. Situasi ini menyebabkan kematian balita mencapai 3 juta kematian setiap tahun (Black et al., 2013). Status gizi yang buruk menempatkan anak pada risiko kematian yang tinggi akibat penyakit infeksi karena rendahnya imunitas. Selain itu, anak yang pernah mengalami gizi buruk akan mengalami keterlambatan perkembangan motorik, kognitif dan perilaku (Katona \& Judit, 2008).

Prevalensi gizi kurang secara global mengalami penurunan dari $25 \%$ pada tahun 1990 menjadi 15\% pada tahun 2013. Pada tahun 2013, sebanyak 99 juta balita mengalami gizi kurang, 2/3 dari angka tersebut berasal dari Asia dan 1/3 berasal dari Afrika. Afrika mengalami penurunan prevalensi gizi kurang yaitu 23\% pada tahun 1990 menjadi 17\% pada tahun 2013. Sedangkan Asia mengalami penurunan prevalensi yang lebih besar yaitu dari 32\% pada tahun 1990 menjadi 18\% pada tahun 2013 (UNICEF et al., 2013).

Asia menempati urutan teratas untuk prevalensi balita gizi kurang pada tahun 2011 yaitu sebesar 21,9\%. Selain itu, Asia juga merupakan benua dengan jumlah total tertinggi untuk balita pendek, kurus dan gizi kurang yaitu 103,5 juta balita pendek, 39,2 juta balita kurus dan 76,6 juta balita gizi kurang pada tahun 2011. Dari 5 wilayah di Asia, Asia Tenggara merupakan wilayah tertinggi kedua untuk jumlah anak dengan gizi kurang yaitu mencapai 9,7 juta $(18,3 \%)$ balita.
Hasil Riset Kesehatan Dasar (Riskesdas) menunjukkan prevalensi gizi kurang di Indonesia pada tahun 2013 sebesar 19,6\%, angka ini mengalami peningkatan dibandingkan dengan tahun 2010 yaitu 17,9\%. Prevalensi gizi buruk juga mengalami peningkatan pada tahun 2013 yaitu sebesar $5,7 \%$ dibandingkan dengan prevalensi gizi buruk pada tahun 2010 sebesar $4,5 \%$.

Menurut hasil Riskesdas tahun 2013 prevalensi gizi kurang dan gizi buruk pada anak balita di Provinsi Sulawesi Selatan sebesar $25,6 \%$, yang berarti masalah gizi kurang dan gizi buruk di Sulawesi Selatan masih merupakan masalah kesehatan masyarakat dengan prevalensi tinggi. Sulawesi Selatan menempati urutan ke-10 untuk angka prevalensi status gizi buruk pada balita berdasarkan pengukuran $\mathrm{BB} / \mathrm{U}$ pada tahun 2013 yaitu sebesar 6,6\%. Sedangkan prevalensi gizi kurang di Provinsi Sulawesi Selatan pada tahun 2013 yaitu sebesar 19,0\%, angka ini masih berada diatas target RPJMN 2010-2014 yaitu sebesar $15 \%$.

Pemerintah Indonesia telah menunjukkan komitmen yang kuat untuk mengatasi masalah gizi kurang dan gizi buruk dengan berbagai kebijakan dan program. Pada tahun 2012, Indonesia melaksanakan Gerakan Nasional Percepatan Perbaikan Gizi dan meluncurkan "Gerakan Nasional Percepatan Perbaikan Gizi dalam rangka Seribu Hari Pertama Kehidupan" (Gerakan 1000 HPK) yang merupakan adaptasi dari gerakan "Scalling Up Nutrition (SUN). Berdasarkan komite SUN, penyebab langsung 
dan tidak langsung gizi buruk diartikan sebagai faktor yang masing-masing memerlukan intervensi gizi yang spesifik dan sensitif.

Intervensi gizi spesifik merupakan intervensi yang dilaksanakan oleh sektor kesehatan yang bersifat jangka pendek yang ditujukan khusus untuk kelompok 1000 HPK dengan kegiatan berupa imunisasi, PMT ibu hamil dan balita, monitoring pertumbuhan balita di Posyandu, suplemen tablet besi-folat ibu hamil, promosi ASI Eksklusif, MP-ASI dan sebagainya. Sedangkan intervensi gizi sensitif merupakan intervensi di luar sektor kesehatan dengan sasaran masyarakat umum, tidak khusus untuk 1000 HPK. Beberapa kegiatan tersebut adalah penyediaan air bersih, sarana sanitasi, berbagai penanggulangan kemiskinan, ketahanan pangan dan gizi, fortifikasi pangan, pendidikan dan KIE Gizi, pendidikan dan KIE Kesehatan, kesetaraan gender, dan lain-lain.

Prevalensi gizi kurang dan gizi buruk sering digunakan untuk menggambarkan status gizi anak pada negara berkembang untuk merencanakan berbagai program gizi. Berbagai metode telah digunakan untuk mengestimasi prevalensi gizi kurang dan gizi buruk. Penelitian De Onis et al (2004), menggunakan metode Pemodelan Linear mixed-effects untuk mengestimasi prevalensi dan jumlah kasus gizi kurang pada anak di berbagai wilayah di dunia pada tahun 1990-2015. Muliyana (2015), menggunakan model dinamis untuk estimasi prevalensi stunting di Provinsi Sulawesi Selatan dengan menggunakan data Riskesdas 2007 dan
2013. Simulasi yang dilakukan menggunakan interval waktu selama 28 tahun yaitu dari tahun 2007 sampai tahun 2035.

Tersedianya data longitudinal gizi kurang dan gizi buruk serta data beberapa indikator sasaran program perbaikan gizi masyarakat seperti pemberian ASI ekslusif, pemberian kapsul vitamin A pada balita dan imunisasi dasar lengkap pada bayi memungkinkan untuk menggunakan berbagai jenis pemodelan, salah satunya adalah pemodelan sistem dinamis.

Pendekatan model dinamis dapat menggambarkan prevalensi gizi kurang dan gizi buruk yang merupakan bagian dari sistem kompleks pada dunia nyata ke dalam model sederhana. Hal ini penting mengingat tingginya prevalensi gizi kurang dan gizi buruk di Sulawesi Selatan. Penelitian ini bertujuan untuk mengestimasi prevalensi gizi kurang dan gizi buruk di Sulawesi Selatan tahun 2007 hingga tahun 2025 dan diharapkan dapat menunjang pengambilan keputusan pada masa mendatang dalam upaya penurunan prevalensi gizi kurang dan gizi buruk di Sulawesi Selatan.

\section{BAHAN DAN METODE}

\section{Lokasi dan Desain Penelitian}

Penelitian ini dilaksanakan di Dinas Kesehatan Provinsi Sulawesi Selatan. Jenis penelitian ini adalah deskriptif dengan rancangan cross-sectional.

\section{Populasi dan sampel}

Populasi pada penelitian ini adalah data Laporan Dinas Kesehatan Provinsi Sulawesi Selatan. Adapun sampel penelitian yaitu seluruh 
data yang terkait dengan variabel penelitian yaitu gizi kurang, gizi buruk, pemberian ASI eksklusif, pemberian kapsul vitamin A, dan imunisasi dasar lengkap pada bayi.

\section{Teknik Pengumpulan Data}

Penelitian ini menggunakan data sekunder yang diperoleh dari Seksi Gizi Dinas Kesehatan Provinsi Sulawesi Selatan. Data yang akan digunakan adalah data selama 9 (sembilan) tahun yaitu mulai tahun 2007 sampai dengan tahun 2015. Selain itu, digunakan pula data hasil Riskesdas tahun 2007, 2010 dan 2013 serta data Pemantauan Status Gizi (PSG) tahun 2014 dan 2015.

\section{Analisis dan Penyajian data}

Analisis data dilakukan dengan analisis sistem dinamik dengan menggunakan program powersim. Analisis ini dilakukan untuk memprediksi prevalensi gizi kurang dan gizi buruk selama 18 tahun (2007-2025) dan menentukan strategi yang paling sesuai dalam upaya penurunan kejadian gizi kurang dan gizi buruk.

\section{HASIL}

Penelitian ini menunjukkan Tabel 1 menunjukkan prevalensi gizi kurang dan gizi buruk tertinggi pada tahun 2014 yaitu sebesar $26.1 \%$ dengan prevalensi gizi kurang sebesar $20.5 \%$ dan prevalensi gizi buruk sebesar 5.6\%. Prevalensi gizi kurang dan gizi buruk tertinggi pada tahun 2014 yaitu sebesar $26.1 \%$ yang berasal dari data Pemantauan Status Gizi (PSG).

\begin{tabular}{llll}
\multicolumn{3}{c}{$\begin{array}{c}\text { Tabel 1 Distribusi Prevalensi gizi kurang dan } \\
\text { gizi buruk di Provinsi Sulawesi Selatan } \\
\text { Tahun 2007-2015 }\end{array}$} \\
\hline $\begin{array}{l}\text { Tahun } \\
\text { Prevalensi } \\
\text { gizi } \\
\text { kurang }\end{array}$ & $\begin{array}{l}\text { Prevalensi } \\
\text { gizi buruk }\end{array}$ & $\begin{array}{l}\text { Prevalensi } \\
\text { gizi kurang } \\
\text { + buruk }\end{array}$ \\
\hline $2007 *$ & 12.6 & 5.2 & 17.8 \\
2008 & 14.5 & 1.8 & 16.3 \\
2009 & 15.7 & 6.7 & 22.4 \\
$2010^{*}$ & 18.6 & 6.4 & 25.0 \\
2011 & 5.9 & 0.5 & 6.4 \\
2012 & 13.9 & 4.8 & 18.7 \\
$2013 *$ & 19.0 & 6.6 & 25.6 \\
$2014 * *$ & 20.5 & 5.6 & 26.1 \\
$2015 * *$ & 17.1 & 5.1 & 22.2 \\
\hline
\end{tabular}

* Data Riskesdas

** Data Pemantauan Status Gizi (PSG)

Sumber: Dinkes Prov Sulsel, 2016

Pematauan status gizi secara rutin merupakan bentuk komitmen untuk menjaga akuntabilitas pelaksanaan program melalui penyediaan data dan informasi berbasis bukti dan spesifik wilayah untuk daerah dan pusat. PSG mulai dilaksanakan pada tahun 2014, namun pada tahun 2014 hanya 7 Kabupaten di Sulawesi Selatan yang melaksanakan PSG yaitu Kabupaten Bone, Bulukumba, Luwu, Maros, Palopo, Sidrap dan Takalar. Pada tahun 2015, PSG telah dilaksanakan pada seluruh Kabupaten/Kota di Provinsi Sulawesi Selatan. 
Tabel 2 Estimasi Prevalensi gizi kurang dan gizi buruk tahun 2007-2025 di Sulawesi Selatan

\begin{tabular}{|c|c|c|c|c|c|c|c|c|}
\hline \multirow[b]{2}{*}{ Tahun } & \multicolumn{2}{|c|}{ Model I (Tanpa Kontrol) } & \multicolumn{2}{|c|}{$\begin{array}{l}\text { Model II (Penimbangan } \\
\text { Balita di Posyandu) }\end{array}$} & \multicolumn{2}{|c|}{$\begin{array}{l}\text { Model III (Pemberian } \\
\text { ASI Ekslusif) }\end{array}$} & \multicolumn{2}{|c|}{$\begin{array}{c}\text { Model IV (Imunisasi } \\
\text { dasar lengkap) }\end{array}$} \\
\hline & $\begin{array}{c}\text { Estimasi } \\
\text { Prevalensi } \\
\text { gizi } \\
\text { kurang } \\
\text { dan gizi } \\
\text { buruk }\end{array}$ & $\begin{array}{c}\text { Laju } \\
\text { peningkatan } \\
\text { prevalensi } \\
\text { gizi kurang } \\
\text { dan gizi } \\
\text { buruk } \\
\text { pertahun }\end{array}$ & $\begin{array}{c}\text { Estimasi } \\
\text { Prevalensi } \\
\text { gizi } \\
\text { kurang } \\
\text { dan gizi } \\
\text { buruk }\end{array}$ & $\begin{array}{c}\text { Laju } \\
\text { peningkatan } \\
\text { prevalensi } \\
\text { gizi kurang } \\
\text { dan gizi } \\
\text { buruk } \\
\text { pertahun }\end{array}$ & $\begin{array}{c}\text { Estimasi } \\
\text { Prevalensi } \\
\text { gizi } \\
\text { kurang } \\
\text { dan gizi } \\
\text { buruk }\end{array}$ & $\begin{array}{c}\text { Laju } \\
\text { peningkatan } \\
\text { prevalensi } \\
\text { gizi kurang } \\
\text { dan gizi } \\
\text { buruk } \\
\text { pertahun }\end{array}$ & $\begin{array}{c}\text { Estimasi } \\
\text { Prevalensi } \\
\text { gizi } \\
\text { kurang } \\
\text { dan gizi } \\
\text { buruk }\end{array}$ & $\begin{array}{c}\text { Laju } \\
\text { peningkatan } \\
\text { prevalensi } \\
\text { gizi kurang } \\
\text { dan gizi } \\
\text { buruk } \\
\text { pertahun }\end{array}$ \\
\hline 2007 & 17.8 & 0 & 17.8 & 0 & 17.8 & 0 & 17.8 & 0 \\
\hline 2008 & 17.7 & -0.1 & 17.64 & -0.16 & 17.67 & -0.13 & 17.66 & -0.14 \\
\hline 2009 & 17.6 & -0.1 & 17.48 & -0.16 & 17.54 & -0.13 & 17.51 & -0.15 \\
\hline 2010 & 17.71 & 0.11 & 17.51 & 0.03 & 17.61 & 0.07 & 17.57 & 0.06 \\
\hline 2011 & 17.6 & -0.11 & 17.34 & -0.17 & 17.48 & -0.13 & 17.42 & -0.15 \\
\hline 2012 & 17.5 & -0.1 & 17.17 & -0.17 & 17.35 & -0.13 & 17.27 & -0.15 \\
\hline 2013 & 17.4 & -0.1 & 17 & -0.17 & 17.21 & -0.14 & 17.12 & -0.15 \\
\hline 2014 & 17.5 & 0.1 & 17.03 & 0.03 & 17.28 & 0.07 & 17.16 & 0.04 \\
\hline 2015 & 17.39 & -0.11 & 16.68 & -0.35 & 17.14 & -0.14 & 17.01 & -0.15 \\
\hline 2016 & 17.29 & -0.1 & 16.68 & 0 & 17 & -0.14 & 16.85 & -0.16 \\
\hline 2017 & 17.18 & -0.11 & 16.5 & -0.18 & 16.86 & -0.14 & 16.7 & -0.15 \\
\hline 2018 & 17.28 & 0.1 & 16.52 & 0.02 & 16.92 & 0.06 & 16.74 & 0.04 \\
\hline 2019 & 17.17 & -0.11 & 16.34 & -0.18 & 16.78 & -0.14 & 16.58 & -0.16 \\
\hline 2020 & 17.06 & -0.11 & 16.16 & -0.18 & 16.63 & -0.15 & 16.41 & -0.17 \\
\hline 2021 & 16.95 & -0.11 & 15.97 & -0.19 & 16.48 & -0.15 & 16.25 & -0.16 \\
\hline 2022 & 17.04 & 0.09 & 15.98 & 0.01 & 16.54 & 0.06 & 16.28 & 0.03 \\
\hline 2023 & 16.93 & -0.11 & 15.79 & -0.19 & 16.39 & -0.15 & 16.11 & -0.17 \\
\hline 2024 & 16.81 & -0.12 & 15.6 & -0.19 & 16.24 & -0.15 & 15.94 & -0.17 \\
\hline 2025 & 16.7 & -0.11 & 15.41 & -0.19 & 16.08 & -0.16 & 15.77 & -0.17 \\
\hline \multicolumn{2}{|c|}{ Rata-rata per tahun } & 0.058 & & -0.126 & & -0.091 & & -0.107 \\
\hline
\end{tabular}


Tabel 3 Perbandingan Output Estimasi Prevalensi Gizi Kurang dan Gizi Buruk Model Pertama (I) dengan Data Real Tahun 2007-2015

\begin{tabular}{lrrrrr}
\hline \multirow{2}{*}{ Tahun } & Real & Estimasi & \multicolumn{2}{c}{ Mean } & $\boldsymbol{p}$ \\
\hline 2007 & 17.8 & 17.8 & & & \\
2008 & 16.3 & 17.7 & & & \\
2009 & 22.4 & 17.6 & & & \\
2010 & 25 & 17.71 & & & \\
2011 & 6.49 & 17.6 & 20.065 & \\
2012 & 18.7 & 17.5 & & & \\
2013 & 25.6 & 17.4 & & \\
2014 & 26.1 & 17.5 & & \\
2015 & 22.2 & 17.39 & & \\
\hline
\end{tabular}

Gambar 1. Peta prevalensi gizi kurang dan gizi buruk di Provinsi Sulawesi Selatan menurut kabupaten/kota Tahun 2007, 2013 dan 2015

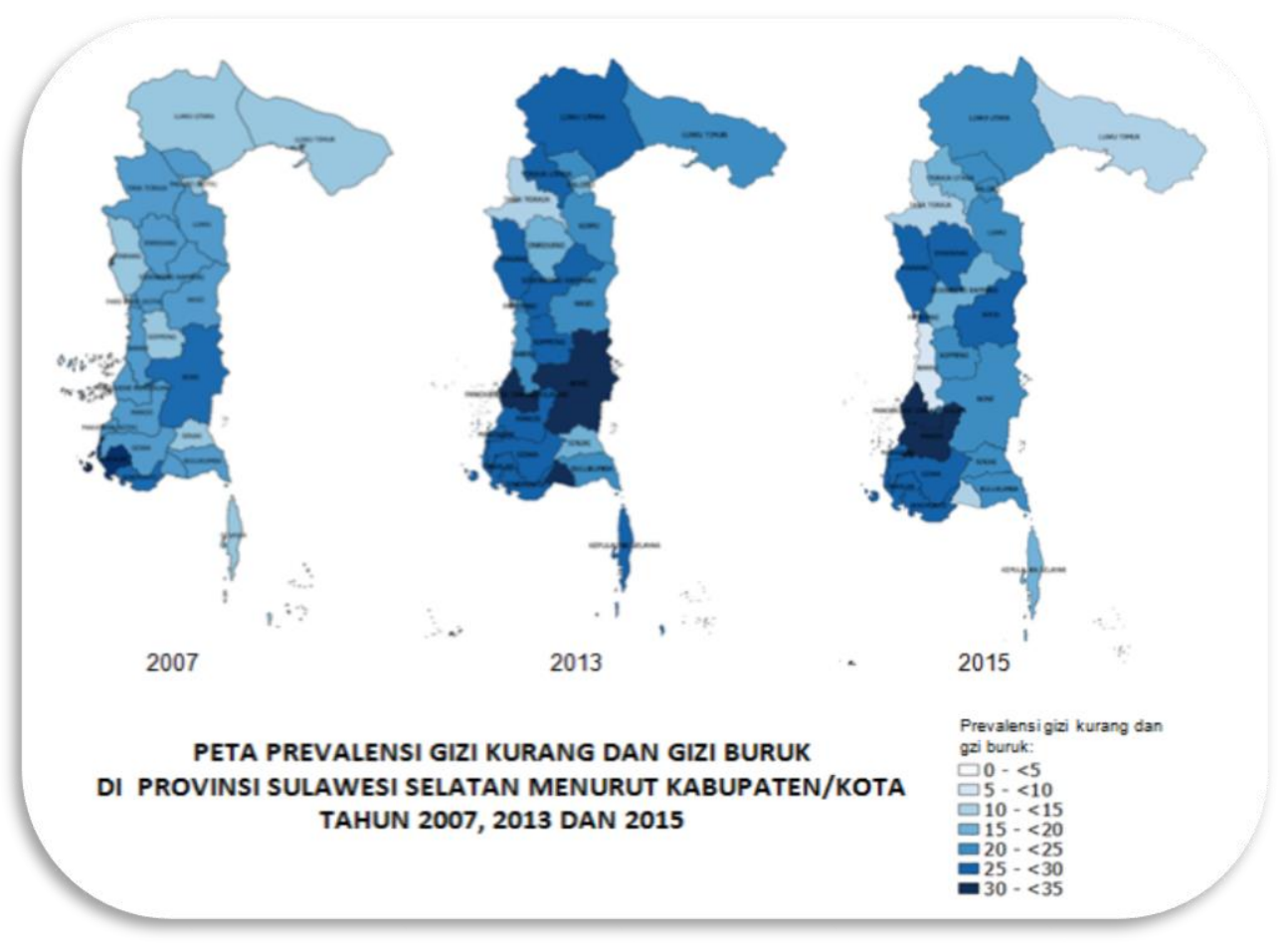


Gambar 2. Estimasi Prevalensi gizi kurang dan gizi buruk tahun 2007-2025 di Sulawesi Selatan

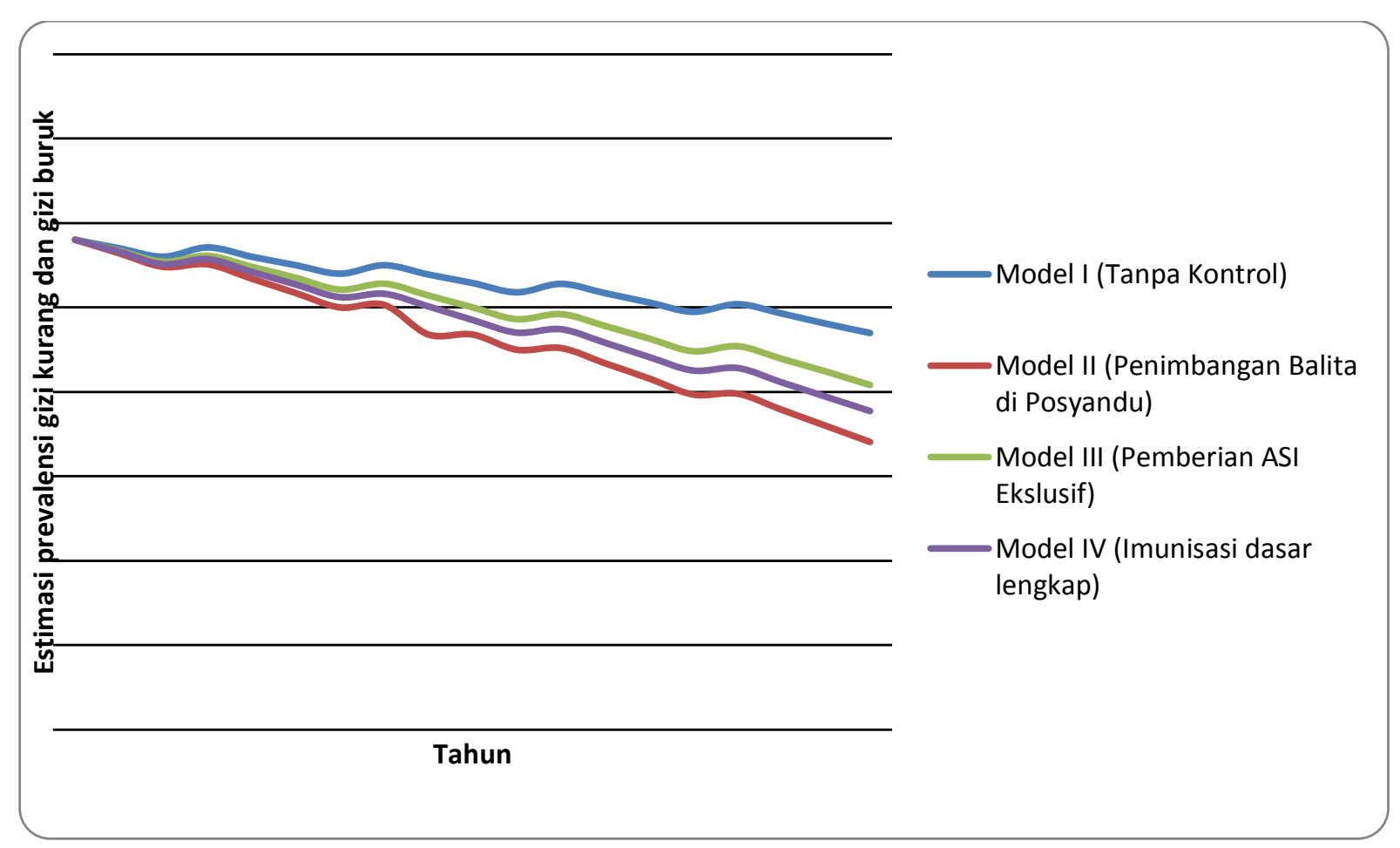

Gambar 1 menunjukkan prevalensi gizi kurang dan gizi buruk menurut Kabupaten/Kota. Kabupaten yang mempunyai prevalensi gizi kurang dan gizi buruk tertinggi pada tahun 2007 adalah Kabupaten Takalar (27.1\%) dan Bone (22.3\%), pada tahun 2013 adalah Kabupaten Bantaeng (33.2\%) serta pada tahun 2015 adalah Kabupaten Maros (30.8\%) dan Kabupaten Pangkep (31.7\%).

Tabel 2 menunjukkan hasil simulasi model dinamis estimasi prevalensi gizi kurang dan gizi buruk. Pada model I menunjukkan bahwa selama 18 tahun (2007-2025) prevalensi gizi kurang dan gizi buruk mengalami penurunan dari $17.8 \%$ pada tahun 2007 menjadi $16.70 \%$ pada tahun 2025 dengan rata-rata peningkatan sebesar $0.058 \%$ pertahun tanpa kontrol terhadap upaya penanggulangan gizi kurang dan gizi buruk.

Model II menunjukkan bahwa selama 18 tahun (2007-2025) prevalensi gizi kurang dan gizi buruk mengalami penurunan dari $17.8 \%$ pada tahun 2007 menjadi $15.41 \%$ pada tahun 2025 dengan rata-rata penurunan sebesar $0.126 \%$ pertahun dengan kontrol penimbangan balita di posyandu. Artinya dengan meningkatkan cakupan penimbangan balita di posyandu menjadi $100 \%$ maka dapat menurunkan prevalensi gizi kurang dan gizi buruk sebesar $0.126 \%$ setiap tahunnya.

Model III menunjukkan bahwa selama 18 tahun (2007-2025) prevalensi gizi kurang dan gizi buruk mengalami penurunan dari $17.8 \%$ pada tahun 2007 menjadi $16.08 \%$ pada tahun 2025 dengan rata-rata penurunan sebesar $0.091 \%$ 
pertahun dengan kontrol pemberian ASI eksklusif. Artinya dengan meningkatkan cakupan pemberian ASI eksklusif menjadi $80 \%$ maka dapat menurunkan prevalensi gizi kurang dan gizi buruk sebesar $0.091 \%$ setiap tahunnya.

Model IV menunjukkan bahwa selama 18 tahun (2007-2025) prevalensi gizi kurang dan gizi buruk mengalami penurunan dari $17.8 \%$ pada tahun 2007 menjadi $15.77 \%$ pada tahun 2025 dengan rata-rata penurunan sebesar $0.107 \%$ pertahun dengan kontrol imunisasi dasar lengkap. Artinya dengan meningkatkan cakupan imunisasi dasaar lengkap menjadi $90 \%$ maka dapat menurunkan prevalensi gizi kurang dan gizi buruk sebesar $0.107 \%$ setiap tahunnya.

Gambar 2 menunjukkan perbandingan hasil simulasi model I, II, III dan IV. Gambar tersebut menunjukkan bahwa, hasil simulasi model IV menunjukkan penurunan prevalensi tertinggi diantara ketiga model lainnya.

Tabel 3 adalah Perbandingan Output Estimasi Prevalensi Gizi Kurang dan Gizi Buruk Model Pertama (I) dengan Data Real Tahun 20072015 yang menunjukkan bahwa $\mathrm{p}>0,05$ berarti tidak ada perbedaan prevalensi gizi kurang dan gizi buruk antara data real (2007-2015) dengan data hasil simulasi model pertama.

\section{PEMBAHASAN}

Penelitian ini memperlihatkan bahwa peningkatan cakupan program penimbangan balita di posyandu menurunkan prevalensi gizi kurang dan gizi buruk sebesar $0.126 \%$ setiap tahunnya, pemberian ASI eksklusif menurunkan prevalensi gizi kurang dan gizi buruk sebesar
$0.091 \%$ setiap tahunnya dan imunisasi dasar lengkap pada bayi menurunkan prevalensi gizi kurang dan gizi buruk sebesar $0.107 \%$ setiap tahunnya.

Pemerintah Indonesia dalam berbagai kebijakan penanggulangan gizi buruk, menempatkan revitalisasi posyandu sebagai salah satu tujuan dalam penanggulangan gizi buruk. Salah satu tujuan khusus pada Rencana Aksi Nasional Pencegahan dan Penanggulangan Gizi Buruk adalah meningkatnya cakupan deteksi dini gizi buruk melalui penimbangan balita bulanan di Posyandu. Terpantaunya status gizi anak melalui penimbangan di Posyandu merupakan alat deteksi dini untuk menemukan balita yang kekurangan gizi.

Pemantauan pertumbuhan dapat memberikan titik masuk untuk perawatan kesehatan preventif dan kuratif dan merupakan bagian integral dari program yang terkait dengan penurunan yang signifikan dalam malnutrisi dan kematian. Dua potensi kekuatan dari pemantauan pertumbuhan adalah bahwa pemantauan pertumbuhan menyediakan kontak dengan petugas kesehatan dan saluran untuk melaksanakan intervensi bagi kesehatan anak (Ashworth et al., 2008). Hasil ini sesuai dengan penelitian Octaviani dkk (2008), yang menunjukkan bahwa responden yang mempunyai kategori tidak aktif di posyandu mempunyai risiko 6,857 kali lebih besar terkena status gizi KEP dibandingkan dengan responden dengan kategori aktif di posyandu. 
Berbagai penelitian telah mengkaji manfaat pemberian Air Susu Ibu (ASI) eksklusif dalam hal menurunkan mortalitas bayi, menurunkan morbiditas bayi, mengoptimalkan pertumbuhan bayi, membantu perkembangan kecerdasan anak. ASI eksklusif terbukti dapat mencegah $13 \%$ kematian bayi, serta menurunkan risiko stunting. Air Susu Ibu (ASI) merupakan makanan terbaik untuk bayi karena mengandung semua bahan yang diperlukan oleh bayi. WHO merekomendasikan semua ibu untuk memberikan ASI eksklusif kepada bayi pada 6 bulan pertama untuk mencapai pertumbuhan yang optimal.

Hasil penelitian Kumar et al (2006), menunjukkan bahwa penundaan pemberian ASI, tidak memberikan colostrum dan pola penyapihan (pemberian makanan tambahan) yang tidak sesuai merupakan faktor risiko kejadian gizi kurang pada anak usia $<5$ tahun. Penelitian Thakur et al (2012), menunjukkan bahwa panjang dan berat badan bayi meningkat secara signifikan setelah pemberian ASI dan pemberikan edukasi gizi bagi ibu.

Terjadi hubungan timbal balik antara kejadian infeksi penyakit dan gizi buruk. Anak yang menderita gizi buruk akan mengalami penurunan daya tahan, sehingga anak rentan terhadap penyakit infeksi. Disisi lain anak yang menderita sakit infeksi akan cenderung menderita gizi buruk. Cakupan pelayanan kesehatan dasar terutama imunisasi, penanganan diare, tindakan cepat pada balita yang tidak naik berat badan, pendidikan, penyuluhan kesehatan dan gizi, dukungan pelayanan di Posyandu, penyediaan air bersih, kebersihan lingkungan akan menentukan tingginya kejadian penyakit infeksi. Mewabahnya berbagai penyakit menular akhir-akhir ini seperti demam berdarah, diare, polio, malaria dan sebagainya secara hampir bersamaan di manamana, menggambarkan melemahnya pelayanan kesehatan yang ada di daerah.

Penelitian Anekwe \& Kumar (2012), menunjukkan bahwa program vaksinasi selain menjadi intervensi utama untuk mengurangi angka kematian anak, juga sebagai alat untuk mengurangi kekurangan gizi di negara berkembang. Penelitian ini juga menambah bukti bahwa program vaksinasi anak-anak merupakan suatu investasi penting karena menghasilkan manfaat kesehatan jangka panjang bagi anakanak.

Beberapa penelitian telah menujukkan bahwa prevalensi gizi buruk dan stunting lebih tinggi pada anak yang tidak mendapatkan imunisasi lengkap. Penelitian Kumar et al (2013), menemukan bahwa pervalensi Protein Energy Malnutrition (PEM) lebih tinggi pada anak yang tidak mendapatkan imunisasi lengkap. Berdasarkan peneltiian tersebut, disimpulkan bahwa status imunisasi dan penyakit yang dapat dicegah seperti diare dan infeksi saluran pernapasan mempunyai peran penting terhadap status gizi anak.

$$
\text { Penelitian Semba et al (2007), }
$$
menunjukkan anak Indonesia yang tidak mengikuti program Imunisasi menunjukkan 
bahwa lebih dari 9\% anak tidak pernah mendapatkan imunisasi, dan $20 \%$ anak tidak mendapatkan imunisasi campak. Berdasarkan hasil analisis dapat disimpulkan bahwa anak yang tidak mendapatkan imunisasi mempunyai angka malnutrisi yang lebih tinggi.

\section{KESIMPULAN DAN SARAN}

Kesimpulan pada penelitian ini adalah peningkatan capaian cakupan program pemberian ASI eksklusif, pemberian kapsul vitamin A dan

\section{DAFTAR PUSTAKA}

Anekwe T D., \& Kumar S. (2012). The effect of a vaccination program on child anthropometry: evidence from India's Universal Immunization Program. Journal of Public Health, 4:489-497.

Ashworth A., Shrimpton R., \& Jamil K. (2008). Growth monitoring and promotion: review of evidence of impact. Maternal \& Child Nutrition, 4:86-117.

Black R E et al. (2013). Maternal and child undernutrition and overweight in lowincome and middle-income countries. The Lancet, 382:427-446.

De Onis M., Blössner M., Borghi E., Frongillo E A., \& Morris R. (2004). Estimates of global prevalence of childhood underweight in 1990 and 2015. Jama, 291: 2600-2606.

Katona P., \& Judit K. A. (2008). The Interaction between Nutrition and Infection. Clinical Infectious Diseases, 46:15821588.

Kumar D., Goel N K., Mittal P C., \& Misra P. (2006). Influence of Infant-feeding Practices on Nutritional Status of Under-five Children. Indian Journal of Pediatrics, 73:417-422. imunisasi dasar lengkap dapat membantu percepatan penurunan prevalensi gizi kurang dan gizi buruk. Mengingat penanggulangan gizi kurang dan gizi buruk membutuhkan kerjasama antar lintas program dan lintas sektoral, maka dibutuhkan peningkatan koordinasi serta kerjasama antar stake holder lintas program dan lintas sektoral untuk percepatan penanggulangan gizi kurang dan gizi buruk.

Kumar S., Kumar S., Ashok N. \& Koppad R. (2013). Protein Energy malnutrition and its association with immunization status and common morbidities among 1-5 year aged children in southern part of India, Mysore. International Journal of Current Research and Review, 5:105110.

Muliyana. (2015). Model Dinamis Prediksi Kejadian Stunting di Sulawesi Selatan. Universitas Hasanuddin (Tesis). Makassar: Universitas Hasanuddin.

Octaviani U., Juniarti N., \& Mardiyah A. (2008). Hubungan Keaktifan Keluarga Dalam Kegiatan Posyandu Dengan Status Gizi Balita Di Desa Rancaekek Kulon Kecamatan Rancaekek (Skripsi). Bandung: Universitas Padjadjaran Bandung.

Semba R D et al. (2007). Malnutrition and infectious disease morbidity among children missed by the childhood immunization program in Indonesia. Southeast Asian journal of tropical medicine and public health, 38:120-129.

Thakur S K et al. (2012). Effect of nutrition education on exclusive breastfeeding for nutritional outcome of low birth weight babies. Eur J Clin Nutr, 66:376-381. 